\title{
Antidiscrimination Meets Integration Policies: Exploring New Diversity-Related Challenges in Europe
}

\author{
Tina Magazzini
}

Citation: Magazzini, Tina. 2021 Antidiscrimination Meets Integration Policies: Exploring New

Diversity-Related Challenges in Europe. Social Sciences 10: 221. https://doi.org/10.3390/socsci 10060221

Academic Editors: Zenia Hellgren and Bálint Ábel Bereményi

Received: 8 March 2021

Accepted: 2 June 2021

Published: 10 June 2021

Publisher's Note: MDPI stays neutral with regard to jurisdictional claims in published maps and institutional affiliations.

Copyright: (C) 2021 by the author. Licensee MDPI, Basel, Switzerland. This article is an open access article distributed under the terms and conditions of the Creative Commons Attribution (CC BY) license (https:/ / creativecommons.org/licenses/by/ $4.0 /)$.
Robert Schuman Centre for Advanced Studies, European University Institute, 50133 Florence, Italy; tina.magazzini@eui.eu

\begin{abstract}
Contemporary European societies are increasingly diverse. Migration both within and to Europe has contributed over the past decades to the rise of new religious, racial, ethnic, social, cultural and economic inequality. Such transformations have raised questions about the (multi-level) governance of diversity in Europe, thus determining new challenges for both scholars and policymakers. Whilst the debate around diversity stemming from migration has become a major topic in urban studies, political science and sociology in Europe, Critical Race Studies and Intersectionality have become central in US approaches to understanding inequality and social injustice. Among the fields where 'managing diversity' has become particularly pressing, methodological issues on how to best approach minorities that suffer from multiple discrimination represent some of the hottest subjects of concern. Stemming from the interest in putting into dialogue the existing American scholarship on CRT and anti-discrimination with the European focus on migrant integration, this paper explores the issue of integration in relation to intersectionality by merging the two frames. In doing so, it provides some observations about the complementarity of a racial justice approach for facing the new diversity-related challenges in European polity. In particular, it illustrates how Critical Race Studies can contribute to the analysis of inequality in Europe while drawing on the integration literature.
\end{abstract}

Keywords: integration; race; migration; Europe; United States

\section{Introduction}

In a globalized yet very unequal world, issues of diversity management linked to the processes that either promote or halt social justice represent an ever more urgent matter. In recent years increasing attention-both scholarly and from a policy perspective-has been paid to ethnic, religious and racialized minorities, and to the need for diversity management stemming from migration flows in particular. One pressing concern for contemporary democracies is how to cope with changes in the composition of their population and how to manage inter-group relations, at a time in which Western countries are also confronted with population aging and with increasing levels of inequality across group lines. Within this field, European and North American research on migration, multiculturalism, diversity and integration share questions and ambitions: how to frame and understand persistent inequalities, immigration and integration patterns through analytical contributions and evidence-based data. Yet, they remain largely disconnected in their methodologies, debates and approaches to these issues.

Whilst Europe has seen the concept of super-diversity (Vertovec 2007; Phillimore et al. 2020), a 'diversification of diversity' and migrant integration become major topics in urban studies, political science and sociology; Critical Race Studies and Intersectionality have become central in US approaches to understanding inequality, racial and social injustice (Crenshaw et al. 1995, 2019).

What this article proposes to do is to look at the terms and the concepts employed to deal with diversity, difference and injustice in the two contexts, to try to understand 
whether they are in practice similar, interchangeable, complementary or at odds with each other or even incompatible. Are we using different terminologies to speak about similar issues? Or are we employing different analytical tools because the matters studied are fundamentally different? Can we compare the policies, claims-making and social movements that rally around the concepts of exclusion and inclusion, race and ethnicity, integration and immigration, (super)diversity and antidiscrimination in Europe and the United States?

The following sections provide an overview of how the main concern for these topics has evolved in recent years in the United States and in Europe, focusing on the development, understanding and use of the concept of 'integration' and what is seen as its opposite. In terms of methodology, this paper draws mainly on secondary data, tracing and contrasting the usage of 'integration' in different political and scholarly contexts. It, however, also includes some excerpts from interviews carried out between February and August 2020 to policy-makers, integration experts and media representatives, which were part of the fieldwork conducted for a broader research project on radicalization, secularism and the governance of religious diversity. ${ }^{1}$ What emerges from comparing the main frameworks employed in continental Europe and the United States are the very different assumptions that lay at the core of ideas of antidiscrimination, race, ethnicity and, ultimately, who constitutes the body politics.

\section{Locating the Issue}

Over the past decades, at a superficial glance at least, it seems that many of the issues confronted by Europe and the United States in terms of increasing diversity are fundamentally of the same nature. As two of the strongest global economies and liberal democratic societies which promote themselves as havens of human rights and the rule of law (regardless of the actual fulfillment of those self-narratives), it is no surprise that both continue to be net-immigration countries, attracting immigrants from different world regions. While the COVID-19 pandemic has temporarily slowed such trend, it is reasonable to expect the percentage of foreign-born population (currently accounting for approximately $7.7 \%$ of residents in the EU, and for $14.5 \%$ in the US) to continue to grow, as well as that of children born in the EU or the US whose parents are immigrants.

Considering the rising share and number of older people in both places, economists broadly agree that receiving countries benefit economically and demographically from the inflow of migrants (Portes 2019), yet immigration is also met with ambivalence, anxiety and hostility by sectors of majority societies that are concerned with what such developments mean in terms of broader changes (Hadj Abdou 2020; Triandafyllidou 2020). These fears and hostility have been mobilized and amplified by political parties and movements that, while putting forward and anti-immigration propaganda, heavily resort to racially coded dog-whistle politics and Islamophobic discourses (Haney López 2014, 2016). Former President Trump's inflammatory claim that the United States should reject immigrants from African and Muslim-majority countries, while attracting more people "from countries like Norway" (BBC 2018) shocked but hardly surprised: the appeal of the alt-right-an appeal which is widespread way beyond MAGA, Fidezs, the Northern League, the Alternative for Germany, or the Law and Justice voters-is clearly not a blanket hostility toward foreigners in general, but rather toward specific 'othered' racialized migrants.

In the United States, the Census Bureau projections showing that African Americans, Asians, Hispanics and other racialized minorities will collectively make up a majority of the population by 2050, have generated mixed responses, with more Americans saying that a majority nonwhite population will have a negative impact on conflicts compared to those who say it will have a positive effect (Parker et al. 2019). The polarization in response to immigration and racial justice protests such as the 2006 immigrant protests and the Black Lives Matter movement are certainly not new, but divides have become even more visible since the killing of George Floyd by a Minneapolis police officer in May 2020. 
Criticism to what is often, pejoratively, labelled as 'identity politics' relies on the idea that a focus on racial, sexual, ethnic or intersectional identity threatens to entrench society into subnational groupings where minority members receive 'preferential treatment', which in turn polarize and divide (Fukuyama 2018). However, this is invariably grounded on the assumption that past politics (one dominated exclusively by white men) was not rooted in identity-that 'identity' is an attribute that does not apply to whites. From the perspective of the still dominant framework that sees the 'Default Man' (western, middle-class, white heterosexual male) as the benchmark of what it means to be 'integrated' or to belong to the 'mainstream' (Magazzini 2017; Perry 2014), this starting point is hardly surprising. This approach has been the framework employed in social sciences, the media and politics for so long that it is ingrained in a myriad of everyday banal conventions, including the ways in which we discuss such issues: "The term white is almost always lowercase, while other ethnic and racial groups are capitalized: Blacks, Latinos, Hispanics, Jews. [ ... ] the unequal stylistic treatment of the words is part and parcel of the cultural and political terrain in which the lowercase indicates the taken-for-grantedness that comes with whiteness" (Hattam 2007, p. xii). The Critical Racial Studies and Intersectional approaches that have emerged in the United States over the past decades question such premise, observing that "The marginalized did not create identity politics: their identities have been forced upon them by dominant groups" (Abrahams 2019).

Meanwhile, in Europe, even as many pro-Europeans gather around the narrative of a European project that is opposed to the right-wing populism and nationalism that has been rising over the past decade, some aspects of racial dog whistling have been incorporated into Europeanism itself (De Genova 2017; Heller et al. 2018). The racial undertones present in discourses around 'European identity' are all the more difficult to address, given that race remains by and large a taboo in continental Europe, relegated to the history of Nazism, Fascism and the Second World War.

It is worth noting that European institutions themselves have no competency over how individual countries define ethnic, racial or national minorities within their territory, and each country retains the sole capacity to carry out census data collection according to their own categories (which are in turn shaped by specific historical legacies, which differ for each country). Speaking about the US and Europe in such broad strokes might therefore run the risk of flattening both realities-which are rich in complexity, nuances and contradictions - into generalizations. That being said, one fundamental difference that can be appreciated between the two contexts is the fact that 'race/ethnicity' as a census category provides, in the United States, a critical tool to assess racial disparities and make policy decisions, while in Europe it only exists in the UK, with most countries ignoring the concept altogether and some-such as France-explicitly forbidding any collection or usage of data referencing race (data protection law 1978, amended in 2004. See Simon 2015).

While in recent years a network of German scholars and activists has written about and challenged Germany's attempts to erase the term 'race' from the German constitution (Barskanmaz and Samour 2020; Roig 2021), the uneasiness in using racial categories in EU countries extends further than the issue of whether census on data collection is allowed or not. Frédérique Vidal, France's Minister of Higher Education, has repeatedly dismissed any call to research racial inequalities and address structural discrimination in higher education with claims such as "In biology, it has been known for a long time that there is only one human species and that there are no races" (Vidal 2021). That there is just one human race is of course indisputable, but such statements (which are widespread in politics at both the national and EU levels) intentionally misunderstand the claims for racial justice by ignoring that race, while not a fact of nature, continues to play a fundamental role as a sociopolitical fact of domination:

Indeed, race is the naturalized effect of a regime of domination orchestrated according to racialized distinctions and categories, which are themselves sociopolitical contrivances. Thus, race is not a fact of nature so much as a fact of 
racism, a fact of racialized domination, configured historically and continuously reproduced on a global scale-particularly the historically specific hierarchies of social power, wealth, and prestige enforced through violent and oppressive regimes of (European/colonial) white supremacy. (De Genova 2017, p. 6)

The erasure of the term 'race' in Europe following the Second World War has not erased racism, but it has caused it to be largely replaced with the term 'ethnicity', which in turn has been increasingly used interchangeably with the concept of cultural identity (especially religious identity, i.e., with 'Arabs' and 'Muslims' being perceived as synonyms). Therefore, while many continue to experience racism, xenophobia and Islamophobia, the inability of speaking about race has turned into an inability to speak about racism in Europe, and to seriously consider affirmative actions as a tool to redress injustices, particularly related to colonialism (El-Tayeb 2008; Lentin 2008).

Against this background, the perception that an unspecified but implicitly white and Christian 'European identity' is under threat-a claim articulated in terms of culture and values but rooted in colonialist legacies and race cleavages-has become more prominent in European right-wing parties. On the other hand, those that present themselves as opposing such narratives, have so far not seriously engaged with the concept of diversity in any other terms than gender diversity, as can be seen in the 2019 claim by EU's Commissioner Ursula von der Leyen that the newly inaugurated, 27-strong team of all-white commissioners was “as diverse as Europe is" (Montalto Monella 2019). Indeed, the European Commission's political leadership has never come as close to gender parity as its current composition, yet it has so far not seriously engaged with issues of representativeness of racialized minorities, that continue to be identified as 'migrants', regardless of whether they were born in Europe.

Kundnani, a non-white British writer, has pointed to the fact that the EU's migration policy, by focusing on 'protecting' a narrowly defined Europe, ends up naturalizing the idea that whiteness constitutes a fundamental characteristic of 'Europeanness' and in doing so it projects different levels of worth onto different categories of migrants, with those who are non-white labeled as a threat:

[ ... ] The most striking expression of this pro-European civilisationalism is that, as part of Von der Leyen's 'geopolitical Commission', the EU now has a Commissioner for Promoting our European Way of Life (it was originally 'for Protecting our European Way of Life'), Margaritis Schinas. His main responsibility is to coordinate the Commission's approach to asylum and migration, which is largely about keeping migrants out, often using brutal methods that violate human rights. This makes the EU's civilisational turn explicit: migration is now seen not just as a difficult issue to be managed but as a threat to the 'European Way of Life'. (Kundnani 2021)

What makes (again, a certain kind of) immigration - in Europe as in the United Statesbe perceived as such a threat, if economically there are more advantages than disadvantages at stake for the receiving societies? Some authors have argued that, with the framing of migration being generally presented as something that is connected to misery and tragedy and/or as a phenomenon that should be prevented, "migration is linked to threat, and immigrants' experiences are constructed as radically different to those of the rest of society, which makes it difficult to identify with migrants as equals" (Hadj Abdou 2020, p. 656). It has also been argued that the rising economic inequality in most Western countries has "pushed the issue of "social integration" or "social cohesion" up the political agenda; but so has the general economic and cultural globalization, the flow of migrants across nation borders and the security concerns after 9/11" (Larsen 2014).

The political playbook of linking migrants to marginality, otherness and insecurity has been harnessed successfully by parties in Europe as in the United States. It should not, however, be assumed that these dynamics play out in the same way, nor that the methodologies and frames employed to pursue 'social integration' are the same. 
As 'unity' and 'integration' have been mobilized in both settings as a remedy to the increasing (real and/or perceived) polarization and threats of violent radicalization, it is worth looking into how 'integration' is declined differently in the two contexts, and in which ways and to what extent it relates to issues of immigration, racism and racialization.

\section{3. 'Integration' Caught between Race, Ethnicity, Class and Their Intersections}

The concept of 'integration' has informed much of the political and social science research on both immigrant settlement and on the struggle for equality of national and/or racialized minorities in Western countries. Heated debates have spurred over whether cultural, linguistic, ethnic and religious minorities are 'integrating enough', over how integration varies across immigrant/national minority groups, and on whether the concept of 'integration' is too state-centered or biased to be of much use (Schinkel 2018), or whether it has simply failed, leading to 'integration exhaustion' and 'race fatigue' (Cashin 2004; Hartman and Squires 2009).

In Europe, what has been branded as a 'two-way integration' (involving the engagement of the host society as well as of immigrants to foster migrant integration) or a 'three-way integration' (in which the country of origin also plays a role, see GarcésMascareñas and Penninx 2016), has become the standard bearer of the EU's (as well as of individual EU countries') approach to integration. As laid out in the EU's 2004 Basic Common Principles for Immigrant Integration Policy "Integration is a dynamic, two-way process of mutual accommodation by all immigrants and residents of Member States" (Council of the European Union 2004, p. 17).

Similarly, the introduction to the European Commission's latest Action plan on Integration and Inclusion (2021-2027) reads, "The integration process involves the host society, which should create the opportunities for the immigrants' full economic, social, cultural, and political participation. It also involves adaptation by migrants who all have rights and responsibilities in relation to their new country of residence" (European Commission 2020, p. 1).

The opportunities to be created by such an integration process are identified in the pillars of housing, education, employment, health and civic participation (or 'active citizenship') which remain the same priorities of previous Action Plans and Strategies: the same 'markers and means' identified in reference to the integration of refugees by Ager and Strang (2008); the same priorities known as the 'Zaragoza indicators', introduced at a 2010 ministerial conference under the Spanish presidency of the EU and then adopted in the 2011 European Agenda for the Integration of Third-Country Nationals; the same indicators that represented the cornerstone of the European Commission 2016 Action Plan on the Integration of Third Country Nationals, as well as of the EU Framework for national Roma integration strategies up to 2020 (adopted by the European Commission in 2011).

Among the criticisms brought to this understanding of integration, one issue that emerges repeatedly is that while individual policy-makers and NGOs working to foster integration at the local level might be competent, dedicated and well intentioned in providing migrants, refugees or Roma with equal access to services, in its current form, integration remains a 'soft policy' approach which simply cannot undo nor subvert structural factors such as institutional discrimination and racial and class inequality (Hellgren 2016; Magazzini 2020). This means that if the concept of 'integration' in the European context is to be usefully employed as a governance technique, its model needs to be rethought to address multiple issues: normativity, the negative objectification of migrants as 'other', an outdated imaginary of society, methodological nationalism, and a narrow focus on migrants in the factors shaping integration processes (Spencer and Charsley 2021). In order to do this, categories such as race and class must be included into the integration framework (Hadj Abdou 2019).

How to do so, however, remains unclear. The goals of the integration process themselves (migrants' active participation and equal access to services) rest on the assumption of a well-functioning, fairly equal society in which the standard, imaginary national citizen 
is him or herself 'integrated' (Figure 1). An advisory report for the European Commission's Home Affairs claims: "Naturalisation is both a final step in a process and a tool to further improve integration in several areas of life. Citizenship is a societal outcome indicator, a policy indicator and a measure of openness of receiving societies, all at the same time" ( Huddleston et al. 2013). But what if being an EU citizen is not automatically a synonym of being integrated in the first place?

Are, for instance, people in prisons (a growing demographic in most EU countries since the 1980s) or homeless individuals integrated, regardless of their citizenship? Given the importance given to civic participation in the abovementioned reports and plans, can an EU national who has never voted in his or her country be considered integrated? Are billionaires, or even millionaires, the vast majority of whom do not interact with the states' public health and education services, integrated? Can citizens who are living below the poverty line be said to be integrated?

As an example, according to official figures in Italy in 2018 over $23 \%$ of youth (1829 years old) belong to the NEET category (neither in education, employment nor in training), while the overall female employment rate in the country has never reached 50\% and is below 34\% for women under 35 (Rosina 2020; ISTAT 2021). In the same period, the overall employment of non-EU migrants in Italy was of $59 \%$ according to governmental statistics (Ministero del Lavoro e delle Poliche Sociali 2018). If one of the main concerns of integration policies is that of fostering access to employment for those sectors of the population who rank poorly in their participation in the economy, it seems that young Italian women residing in their own country of origin might offer a qualified target.

The point of these objections is to raise the broader question: can we speak about 'integrated societies' and of 'migrant integration' into these societies, if most democratic European countries display, to a non-negligible degree, some of the features mentioned above-homelessness, unemployment, high incarceration rates, rising inequality, or significant groups of the population disengaged from the democratic process and institutional representation?

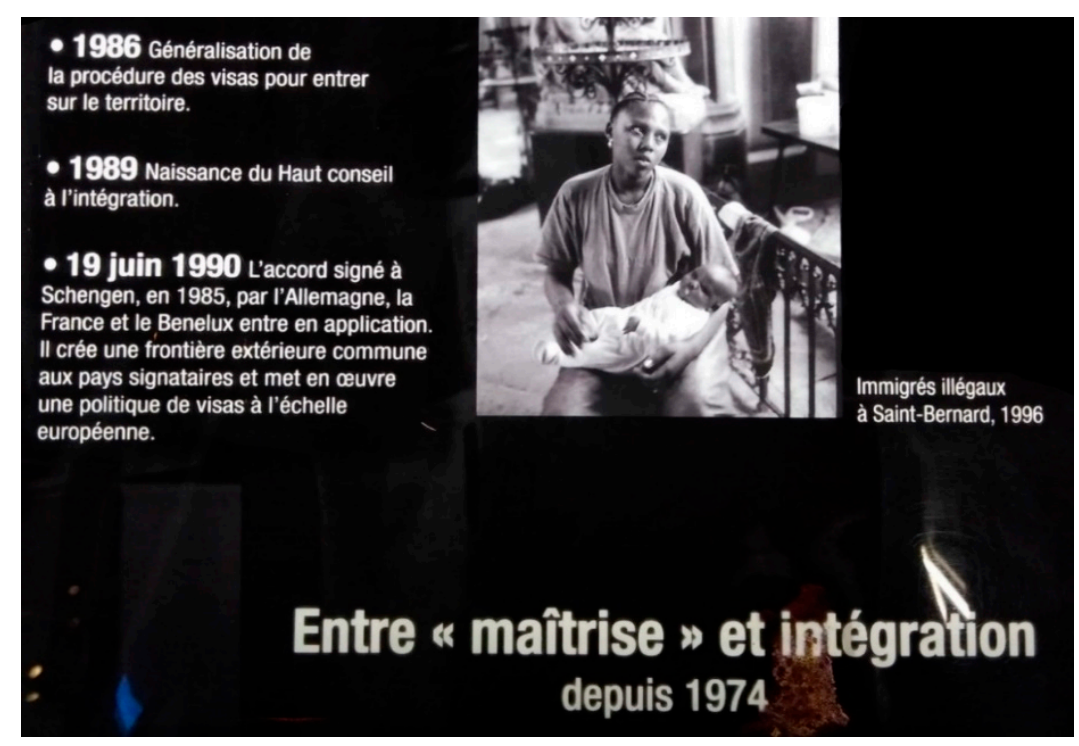

Figure 1. Since the 1980s, the policy of European countries towards migration has focused on two main objectives: to 'manage' and reduce the flow of immigrants through border controls, and to 'integrate' the migrants already present on the territory by increasing their 'skills' (picture taken at the Immigration Museum, Paris, 2020).

The Action Plan on Integration and Inclusion 2021-2027 recently put out by the European Commission prides itself with, as of this year, supporting not only non-EU migrants, but also "EU citizens of migrant background"-arguably the only significant difference in approach compared to previous frameworks, which only saw third country 
nationals as targets or beneficiaries of integration measures. This, however, still begs the questions of whether the disparities in 'integration' between EU citizens of migrant background and EU citizens who are not of migrant background have to do with the formers' parents' histories and 'imported culture', or whether they have to do with the latter's racism.

In other words, if the need for integration-intended as policies promoting participation and equal access to services-can no longer be ascribed (solely) to differences stemming from different citizenship status or to language skills, the extension of such measures to EU nationals 'of migrant background' (i.e., non-white, as those with white American or Australian parents are unlikely to be the target of integration) is an acknowledgement, albeit implicit, of the discrimination suffered by racialized minorities based on the colour of their skin or on the religion they practice.

In the United States, the integration debate has a very different history and terms of reference, one that starts from such an acknowledgement-that because society is profoundly (racially) segregated, specific affirmative actions need to be taken in order to create integration. This means designing policies in ways to include disadvantaged groups, but the ways in which the target group(s) have traditionally been defined differs radically from Europe's focus on migrants.

In the aftermath of the civil war, the main tool to resist and impair the attempt to create a society of racial equality were the Jim Crow laws, enforcing systematic segregation in the South. With whites self-segregating and monopolizing all the opportunities for themselves, from property acquisition to quality education to business ownership, the term integration became mainly associated with the struggle for desegregation, school integration and with Brown v. Board, the sentence with which, on 17 May 1954, the United States Supreme Court declared segregated schools unconstitutional (Figure 2). Of course, despite progress, segregation was not wished away with Brown v. Board, nor with the Civil Rights Act of 1964, the Voting Rights Act of 1965, or the Fair Housing Act of 1968, as blacks in the United States continue to disproportionally attend lower quality schooling, live in poorer neighbourhoods and face constrained access to basic civil rights as voting (Chetty et al. 2018). Many argue that this is because legal segregation was but a manifestation of the problem, the problem remaining that white America has not been willing to give up its socio-economic privilege and continues to fight integration (Hartman and Squires 2009; Ivery and Bassett 2015). In practical terms, this means not only that past structural discrimination continues to affect current inequalities, but also that because of the persistence of 'whiteness as property' (Harris 1993) in the form of federal housing policies, even as legal segregation was overturned, current racial segregation in most major US metropolitan areas is worse today than it was 150 years ago during Reconstruction (Finn 2018).

Integration measures are therefore fragile and depend upon white buy-in, and in the instances in which there has been successful integration, racial minorities have ended up being hostages of the whims and preferences of whites (Gross 2020). 


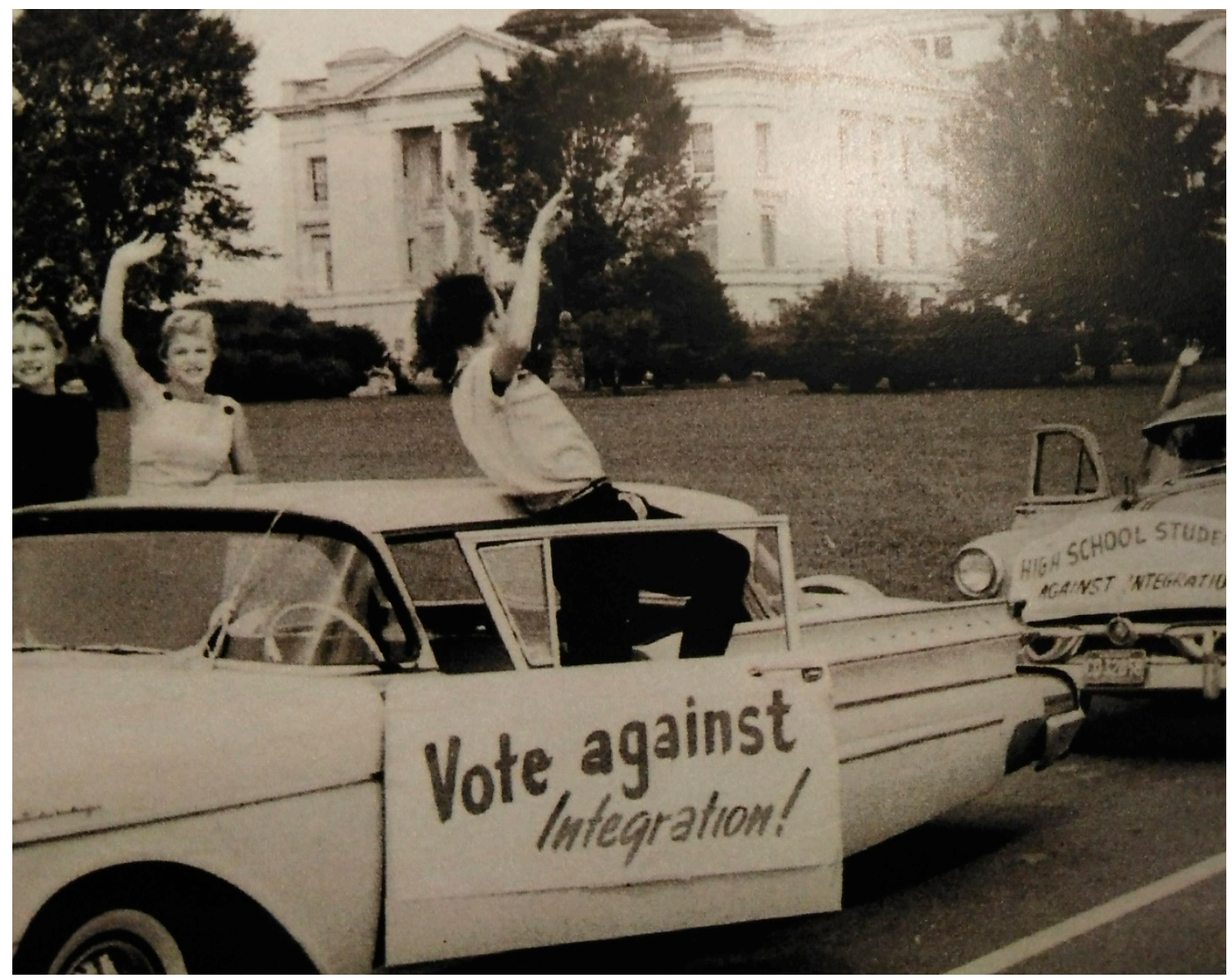

Figure 2. In 1954 the United States Supreme Court ruled segregation in public schools to be unconstitutional in the Brown v. Board of Education case, acknowledging that racially separate schools were inherently unequal. Despite the sentence, the huge backlash against integration by some whites in the south led President Eisenhower in 1957 to dispatch federal troops to protect 9 Black students attending the recently desegregated Central High School in Little Rock, Arkansas. While the civil rights movement of the 1960s and 1970s achieved significant gains in integration, there has been backsliding since in both education and housing segregation (picture from 1957, Little Rock, Arkansas).

What does this concept of integration-one built as a reaction and alternative to racial segregation-mean for migrant minorities in the United States? Immigrants are central to the US identity and history, and yet they are not incorporated into the same integration policies nor efforts aimed at racialized minorities (unless they are Black immigrants, see Hamilton 2018). When American scholars resort to the vocabulary of integration they qualify it as mainly concerned with matters of race, residential segregation and school segregation, rather than with cultural integration or religious diversity, which tend to be the main concern in Western Europe (Alba and Foner 2015). The extensive literature on immigrants in the United States employs instead the concept of assimilation (Zhou 1997; Alba and Nee 2014).

Despite its limitations in scope-since in its focus on racial desegregation it risks neglecting important aspects tied to cultural recognition, and does not provide a strong framework to discuss the role of immigrant groups in society—one fundamental difference that arguably makes the American approach to 'integration' more useful than the European one for the purposes of advancing social justice has to do with the fact that integration is not seen as something that affects exclusively, or mostly, the 'beneficiaries' that are to enter into a society that is seen as already 'whole', but rather as a mechanism by which equality can be achieved.

Elisabeth Anderson, in her The Imperative of Integration, defined integration as the full participation by people from all social sectors and walks of life, on terms of equality, 
in all the institutions of civil society (Anderson 2010). In this context, US scholars of integration are careful to distinguish integration from assimilation, and to specify that integration has to do with creating settings in which people interact as equals, not where one group gets to dictate to another group how to behave.

In terms of who the targets or beneficiaries of integration are, even though it has been argued that letting go of the idea of 'race' in favour of the concept of 'visible continental ancestry' would be helpful to free colour consciousness from assumptions about racial nature (McPherson 2015), the terminology of race is widely employed, and is clearly distinguished from that of ethnicity: "Issues of power and inequality are more readily expressed in a descent-based language of race [heredity, body/blood, hierarchy]; issues of plurality and inclusion are terrain of ethnicity [culture, language/religion, plurality]" (Hattam 2007).

Because it is possible to distinguish between the social construct of 'racial identity' and its linkages to power and inequality, and that of 'ethnic identity', which is used primarily in reference to migrants' country of origin, it is possible to study different mechanisms of the American stratification system, rather than using ethnicity as an imperfect proxy for racialized minorities. This has made comparisons across racial and migrant status possible, such as Tod Hamilton's study, which convincingly shows how the relative success of black immigrants in the US, compared to black natives, can be explained not by culture, but by migrant selectivity (Hamilton 2018).

Ultimately, it seems that how the idea of 'integration' is operationalized, and whether it can help advance equality, depends on how the debate is shaped by who is setting the agenda in each context.

The American debate has traditionally used 'integration' as a reaction to and a remedy to racial segregation, while the European debate tends to employ 'integration' to speak about the process of migrant integration into Europe, creating normative categories of 'successful' versus 'failed' integration. Therefore, the US integration is clearly situated in a racial debate, which has to do with society as a whole, while the EU integration discussion still revolves mainly around individual skills, indicators performance and how to improve them. This creates different kinds of blind spots in the two contexts: in the US, integration is a poor tool for capturing the process of economic mobility and social inclusion of immigrants and their children. In Europe, integration is an inadequate concept to address structural inequalities, since it remains completely detached from non-discrimination law and intersectionality (which exist in their own right in EU legal scholarship, but lack a policy forum comparable to that of 'integration'; see Lawson and Schiek 2011).

In the American context, integration is therefore mainly useful to debate structural and institutional inequalities across racial lines, rather than to understand migrants' positioning in the US: but while 'Europe's integration' claims to be a tool to address both realities, 'American integration' does not.

The ways in which the two approaches translate into more concrete terms can be seen, perhaps, by identifying the opposite of integration. If integration implies achieving social cohesion and a certain level of equality, what does it mean to sit at the opposite end of that spectrum? Does the opposite of integration mean institutional segregation, exclusion, the perpetuation of racial injustice, polarization, marginality, radicalization, failed integration?

What the next section does is look into what these antonyms mean, and do, for the integration and antidiscrimination ideals.

\section{The Opposite of Integration? Anti-Muslim Racism and 'Color-Blindness' in Europe}

In November 2020, on the fifth anniversary of the Paris Bataclan attacks, the EU home affairs ministers released a joint statement condemning terrorism with a text that, despite the numerous revisions which removed the explicit references to Islam and the requests for migrants to "earn a living for oneself", makes a direct link between the concepts of 'failed integration' and radicalization (Boffey 2020). A core passage of the statement reads: "The sense of belonging and equality is of central importance for the social cohesion of our 
modern, pluralist and open societies. Successful integration is of key importance in this regard. Integration is a two-way street. This means that migrants are expected to make an active effort to become integrated" (European Council 2020).

Such declaration on behalf of the EU institution that defines the general political direction and priorities of the European Union confirms the expectation that it is migrants who need to become 'integrated', and not institutions, neighborhoods, schools or parliaments. This expectation, in turn, is directly linked with the difficulty to research race and racism in Europe, and of ethnicity often being used as a proxy for racial categories-with its obvious pitfalls and inconsistencies. In other words, this is what happens when 'race' is replaced by 'ethnicity', 'ethnicity' is replaced by 'culture', and 'culture' is replaced by 'religion', which in turn is presented not as a collective belonging but rather as an individual feature, unrelated to and disconnected from the pervasive and subtle hierarchy of racialized categories.

Such issues become particularly visible when conducting research that is officially unrelated to race, such as religious diversity, but that ends up being entangled into racial narratives (however implicit they might be). While carrying out research about religious governance in France for a European funded project, considerations on discrimination related to Muslims (who constitute France's largest religious minority) invariably spilled into racial and ethnic discourses. An EU migrant who has lived in both the UK and France and was interviewed in Paris in 2020 within the framework of a project on religious diversity governance and radicalization, ${ }^{2}$ summarized her perception of the difference between the UK and France in the following way: "There is a very strong social status hierarchy here in France, and race is a huge part of it. It's not that in the UK there is no racism, of course, but classism is stronger there: so yes, BAME people are over-represented in low paying jobs, but you also see white working poor people-they exist. In Paris, you don't see "white trash" - and I challenge you to find me a bathroom cleaner who's white. So, about the hierarchy: on top of the food chain, there's the 'Parisian' of course. On the bottom, it's either the blacks or the Arabs: depending on how fresh the memory of the latest terrorist attack is" (interview, February 2020).

With recent controversies around what is framed as an 'Islamic separatism' threat, France represents the most visible and extreme case of pushback against Critical Race Theory and Intersectionality, even though narratives about immigrants' 'duty' to achieve a kind of 'cultural integration' is widespread across Europe. For a long time, integration has been seen in EU white papers mainly as a function of migrants' employment status (i.e., the 'high skilled' versus 'low skilled' migrants debate, see Boucher 2016; Fernández-Reino et al. 2020) and legal status (see Hinger and Schweitzer 2020); however, the 'responsibility to integrate' has in recent years increasingly been "displaced to the cultural realm: 'fitting migrants' are not only [no longer] those economically useful to our markets; they must show that they are capable of integrating culturally in our societies as well" (Morondo Taramundi 2016, p. 2).

A journalist from a mainstream French outlet explained her understanding of integration in terms of 'becoming French': “When the 'Muslim veil' ban passed in 2011, it was really well received by the population. French people support it. [ ... ] We require a certain assimilation from people who don't look French to us, or who don't embody what we view as French. It's very difficult for French people to change the image of what a French person looks like-I feel, for example, even though this is shifting and evolving a little bit, that a French person is still a white person" (interview, August 2020).

If the process of integration is seen as becoming a national of one's country of residence by 'shedding' any characteristic that may be viewed as un-national, and if such characteristic of 'Frenchness', 'Italianness', 'Germanness', etc. involve an implicit racial and religious bias, it is easy to see how such a process can end up short-circuiting.

In a speech given by French President Emmanuel Macron in October 2020, "Certain social science theories entirely imported from the United States" were explicitly identified as a danger to "breaking the republic in two" (Onishi 2021). By blaming universities for encouraging the "ethnicization of the social question", the French President inadvertently 
pointed the finger to the fact that recent efforts do decolonialize the curriculum in some departments, can hardly do so in practice without addressing the racialization of inequalities. In the same speech, Macron stated that "The Republic is both a system and a promise. And so, what we must do very strongly is go further along that path."

Indeed, it seems that the French state promises more to its citizens than the United States does, in terms of welfare and opportunity. Yet, whether such promises are kept, and to whom, is less clear. One interviewee claimed, in reference to France's republican ideals ${ }^{3}$ :

France promises more, but it does not deliver more. And the gap between promise and delivery creates specific forms of resentment. And strikingly, every time this happens the response of the French state is to promise even more: including the promise that France is inherently a non-racist country, because of the principle of republican equality, which is a promise that is largely meaningless, since it completely misunderstands the nature and concerns being expressed. (interview, February 2020)

The narrative of non-racism and non-discrimination as the natural consequence of color-blindness is by no means exclusive to France, however.

In September 2019, one week ahead of the OSCE's annual Human Dimension Implementation Meeting, which included the European Union's first ever Anti-Racism and Diversity Week held in the European Parliament, the US Helsinki Commission convened in Washington, D.C., the hearing The State of Diversity and Inclusion in Europe: Race, Rights, and Politics. The hearing and the questions asked by the US Commission to the EU minority representatives bringing their testimony highlighted some of the differences in approaches in ways that are plain yet striking. The issue of what kind of data collection is acceptable in the census, for instance, is one on which Europe and the US still clearly sit at opposite poles of the spectrum. The exchange during the OSCE hearing between US Congresswoman and Helsinki Commissioner Representative Gwen Moore, and French MP Danièle Obono, sums it up quite clearly:

MOORE: it is very akin to the notion that you want to protect the European way of life to talk about égalité, fraternité in France where no one can wear the hijab, where they don't get data and statistics on race [ ... ] So is there no chance that you could legislatively get the government to officially collect data? You've got a census coming up, right, where you count the people. Do you count people every 10 years like we do?

OBONO: There's a census, but it's not based on the same kind of statistic. We don't have race statistics. ${ }^{4}$

In a way, the US census offers a specular picture to that of most European countries: while the Census Bureau has been collecting racial data based on self-identification for decades without this causing major controversies, ${ }^{5}$ the 2018 attempt by the Trump administration to re-introduce a question in the census regarding citizenship status for the 2020 census was seen as extremely contentious and was eventually dropped. This was because it was seen as a tool to disenfranchise many residents who might have chosen not to fill in the census for fear of repercussions based on their migration status, with consequences in redrawing electoral district boundaries (which are based on census data).

As there are understandable reasons for migrants in the US to be wary about a census that includes questions about citizenship, there are, of course, historical reasons and legitimate concerns regarding data collection on racial identity in Europe. Yet, data in most EU countries is collected on other dimensions (gender, migrant status, citizenship, wealth, employment, family composition) that can also be considered sensitive, of that are grounds for discrimination. So, if race is not a fact of nature so much as a fact of racism and of racialized domination, tackling discrimination inevitably requires some assessment of the situation.

The risk, otherwise, is that the 2000 European race directive (Directive 2000/43/EC) remains an empty declaration of intentions: if the dominant narrative is one of a non-racist 
EU, there is hardly a need for anti-racism. And without reliable data on differential access to services and to positions of power, any case of discrimination remains within the realm of the individual and the anecdotal.

If, however, patterns of segregation and disempowerment, rather than individual acts of discrimination, are the fundamental cause of inequality to be addressed-meaning that we do not segregate because people are similar; rather, we think people are similar because they are segregated - then bringing Critical Race Theory into European debates on integration could help us both disentangle some of the intersectional discrimination faced by those who belong, for instance, to both ethnic and racial minorities, as well as dealing with cases such as the Romani minorities in Europe that have long been treated as exceptional and unique (Kóczé 2021). Some efforts in this direction are being made, as can be seen by the creation of the Center for Intersectional Justice, a non-profit organization founded in 2017 and based in Berlin, but such efforts are for the time being carried out by civil society rather than by government institutions (Center for Intersectional Justice 2020).

\section{Bringing Race into European Integration: Non-Discrimination as a Method?}

In Western countries, which claim to have democratic pluralism as their foundation, the issue of how to foster social cohesion while avoiding a backlash on the rights of migrants and racialized minorities is particularly salient.

With the surge of an extraordinary populist conjuncture in the past few years, migrant and minorities integration and diversity management feature more prominently than ever in national and European research and policy agendas (Brubacker 2017). But what does an integrated society actually look like?

This article sketched out in broad strokes some of the differences in how the ideal of integration and antidiscrimination is narrated - and pursued-in Europe and the United States. Overall, the greatest divergence seems to rest on whether 'integration' is used in reference to a social whole (that individuals 'integrate into'), or whether it is a tool to achieve greater equality (in the form of an integrated society).

The question raised by the existing different approaches then is, can we speak about integration without speaking about its 'targets' or 'beneficiaries', be they immigrants, citizens of migrant origin, Roma or black citizens? I believe we can (and should), but what needs then to be fleshed out is that it is impossible, instead, to research integration without looking not only at inequality and social justice, but at where the structures of those inequalities emerged from.

As James Baldwin eloquently put it over half a century ago: "We talk about integration in America as though it were some great, new conundrum. The problem in America is that we've been integrated for a very long time. Put me next to any African, and you will see what I mean. [ ... ] What we are not facing are the results of what we've done. What one begs the American people to do, for all our sakes, is simply to accept our history" (Baldwin 1965).

If the United States, over the past years, has started to reflect upon its history (if not quite to accept it), Europe's conundrum lays precisely in the fact that its incapacity or unwillingness to do so hampers, and will continue to hamper, its efforts towards building an integrated society.

Acknowledgments: I am grateful to Zenia Hellner and Ábel Bereményi for coordinating the special issue "Racialized Citizenship in Superdiverse Europe", to Martino Serapioni and Licia Cianetti for starting the conversation that led to this article, and to the anonymous reviewers for their constructive feedback.

Funding: This research has received funding from the European Union's Horizon 2020 research and innovation programme under grant agreement number 770640 .

Institutional Review Board Statement: The study was conducted according to the guidelines of the Declaration of Helsinki, and approved by the Ethics Committee of the European University Institute (GREASE project, grant number 770640, ethical approval issued on 23 May 2019). 
Informed Consent Statement: Informed consent was obtained from all subjects involved in the study.

Conflicts of Interest: The author declares no conflict of interest.

\section{Notes}

1 The interviews were carried out in Paris and online to French practitioners and policy-makers, as well as to officers of international organizations working on diversity and anti-discrimination. For more information on the project, see grease.eui.eu. The GREASE project has received funding from the European Union's Horizon 2020 research and innovation programme under grant agreement number 770640 .

2 Nine semi-structured interviews were carried out between February and August 2020 on the governance of religious diversity and of violent radicalization in France, as part of the research conducted for the report "Radicalisation and Resilience Case Study: France". Details on the methodology as well as the full report are available at http://grease.eui.eu/publications/radicalisationand-resilience-case-studies/, accessed on 9 June 2021.

3 For an in depth discussion on the concept of French republicanism, see (Roy 2005; Sealy and Modood 2021).

4 The full transcript of the 2019 hearing is available at https:/ / www.csce.gov / international-impact/events/state-diversity-andinclusion-europe, accessed on 28 May 2021.

5 The current five minimum categories employed by the US Office of Management and Budget (OBM) are White, Black or African American, American Indian or Alaska Native, Asian, and Native Hawaiian or Other Pacific Islander. The reason stated for data collection is that such data is employed in policy decisions, to promote equal employment opportunities and to assess racial disparities in health and environmental risks. See https://www.census.gov/topics/population/race/about.html, accessed on 27 May 2021.

\section{References}

Abrahams, Stacey Y. 2019. Identity Politics Strengthens Democracy. Foreign Affairs. Available online: https:/ www.foreignaffairs.com/ articles / 2019-02-01/stacey-abrams-response-to-francis-fukuyama-identity-politics-article (accessed on 9 June 2021).

Ager, Alastair, and Alison Strang. 2008. Understanding integration: A conceptual framework. Journal of Refugee Studies 21: 166-91. [CrossRef]

Alba, Richard, and Nancy Foner. 2015. Strangers No More: Immigration and the Challenges of Integration in North America and Western Europe. Princeton: Princeton University Press.

Alba, Richard, and Victor Nee. 2014. Assimilation Theory for an Era of Unprecedented Diversity. In Social Stratification: Class, Race and Gender in Sociological Perspective, 4th ed. Edited by David B. Grusky. Boulder: Westview Press, pp. 721-28.

Anderson, Elizabeth. 2010. The Imperative of Integration. Princeton: Princeton University Press.

Baldwin, James. 1965. Debate with William F. Buckley at Cambridge University's Union Hall. Available online: https: / www.folger. edu/sites/default/ files/NJADO-Baldwin.pdf (accessed on 9 June 2021).

Barskanmaz, Cengiz, and Nahed Samour. 2020. The Prohibition of Discrimination Based on Race. Verfassungsblog. Available online: https://verfassungsblog.de/das-diskriminierungsverbot-aufgrund-der-rasse/ (accessed on 28 May 2021).

BBC. 2018. Donald Trump: Shock over US President's Migrants Remarks. BBC News. January 12. Available online: https:/ /www.bbc. $\mathrm{com} /$ news/world-us-canada-42661435 (accessed on 31 March 2021).

Boffey, Daniel. 2020. Violent Extremism Linked to Failure of Migrants to Integrate, EU Says. The Guardian. November 13. Available online: https:/ / www.theguardian.com/world/2020/nov/13/violent-extremism-migrants-failure-to-integrate-eu (accessed on 9 June 2021).

Boucher, Anna. 2016. Gender, Migration and the Global Race for Talent. Manchester: Manchester University Press.

Brubacker, Rogers. 2017. Between nationalism and civilizationism: The European populist moment in comparative perspective. Ethnic and Racial Studies 40: 1191-226. [CrossRef]

Cashin, Sheryll. 2004. The Failures of Integration: How Race and Class Are Undermining the American Dream. New York: Public Affairs.

Center for Intersectional Justice. 2020. Intersectional Discrimination in Europe: Relevance, Challenges and Ways Forward. A Report Commissioned by the European Network Against Racism (ENAR). Available online: https://www.intersectionaljustice.org/ img/intersectionality-report-FINAL_yizq4j.pdf (accessed on 9 June 2021).

Chetty, Raj, Nathaniel Hendren, Maggie R. Jones, and Sonya R. Porter. 2018. Race and Economic Opportunity in the United States: An Intergenerational Perspective. Working Paper 24441. Cambridge: National Bureau of Economic Research, Available online: http:/ / www.nber.org/papers/w24441 (accessed on 9 June 2021).

Council of the European Union. 2004. Press Release 14615/04 (Presse 321), 2618th Council Meeting, Justice and Home Affairs. Brussels. November 19. Available online: https:/ / ec.europa.eu/migrant-integration/librarydoc/common-basic-principles-for-immigrantintegration-policy-in-the-eu (accessed on 9 June 2021).

Crenshaw, Kimberlé Williams, Luke Charles Harris, Daniel Martinez HoSang, and George Lipsitz. 2019. Seeing Race again. Countering Colorblindness across the Disciplines. Berkeley: University of California Press.

Crenshaw, Kimberlé Williams, Neil Gotanda, Gary Peller, and Kendall Thomas. 1995. Critical Race Theory: The Key Writings That Formed the Movement. New York: New Press. 
De Genova, Nicholas. 2017. The "migrant crisis" as racial crisis: Do Black Lives Matter in Europe? Ethnic and Racial Studies 41: $1765-82$. [CrossRef]

El-Tayeb, Fatima. 2008. The Birth of a European Public: Migration, Postnationality and Race in the Uniting of Europe. American Quarterly 60: 649-70. [CrossRef]

European Commission. 2020. Communication from the Commission to the European Parliament, the Council, the European Economic and Social Committee and the Committee of the Regions. Action Plan on Integration and Inclusion 2021-2027. (COM 758 Final). Available online: https:/ / ec.europa.eu/migrant-integration/news/the-ec-presents-its-eu-action-plan-on-integrationand-inclusion-2021-2027 (accessed on 9 June 2021).

European Council. 2020. Joint Statement by the EU Home Affairs Ministers on the Recent Terrorist Attacks in Europe. Available online: https:/ / www.consilium.europa.eu/en/press/press-releases/2020/11/13/joint-statement-by-the-eu-home-affairsministers-on-the-recent-terrorist-attacks-in-europe/ (accessed on 9 June 2021).

Fernández-Reino, Mariña, Madeleine Sumption, and Carlos Vargas-Silva. 2020. From Low-Skilled to Key Workers: The Implications of Emergencies for Immigration Policy. Oxford Review of Economic Policy 36: S382-S396. [CrossRef]

Finn, Johnny. 2018. Living Together/Living Apart. Geography of Segregation in the 21st Century: Mapping Segregation. Available online: https:/ / www.livingtogetherlivingapart.com/mapping-segregation (accessed on 9 June 2021).

Fukuyama, Francis. 2018. Against Identity Politics. The New Tribalism and the Crisis of Democracy. Foreign Affairs. Available online: https:/ / www.foreignaffairs.com/articles/americas/2018-08-14/against-identity-politics-tribalism-francis-fukuyama (accessed on 9 June 2021).

Garcés-Mascareñas, Blanca, and Rinus Penninx. 2016. Integration Processes and Policies in Europe. Contexts, Levels and Actors. Cham: Springer.

Gross, Terry. 2020. Podcast Examines How ‘Nice White Parents' Become Obstacles In Integrated Schools. NPR Education. October 20. Available online: https:/ /www.npr.org/2020/10/12/922092481/podcast-examines-how-nice-white-parents-become-obstaclesin-integrated-schools (accessed on 9 June 2021).

Hadj Abdou, Leila. 2019. Immigrant integration: The governance of ethno-cultural differences. Comparative Migration Studies 7: 15. [CrossRef]

Hadj Abdou, Leila. 2020. Push or Pull? Framing immigration in times of crisis in the European Union and the United States. Journal of European Integration 42: 643-58. [CrossRef]

Hamilton, Tod G. 2018. Immigration and the Remaking of Black America. New York: Russell Sage Foundation.

Haney López, I. 2014. Dog Whistle Politics: How Coded Racial Appeals Have Reinvented Racism and Wrecked the Middle Class. New York: Oxford University Press.

Haney López, Ian. 2016. This Is How Trump Convinces His Supporters They're Not Racist. The Nation. August 2. Available online: https:/ / www.thenation.com/article/archive/this-is-how-trump-supporters-convince-themselves-theyre-not-racist/ (accessed on 9 June 2021).

Harris, Cheryl. 1993. Whiteness as Property. Harvard Law Review 106: 1707-91. [CrossRef]

Hartman, Chester, and Gregory Squires. 2009. The Integration Debate: Competing Futures for American Cities. London: Routledge.

Hattam, Victoria. 2007. In the Shadow of Race. Jews, Latinos, and Immigrants Politics in the United States. Chicago and London: The University of Chicago Press.

Heller, Charles, Lorenzo Pezzani, Itamar Mann, Violeta Moreno-Lax, and Eyal Weizman. 2018. It's an Act of Murder: How Europe Outsources Suffering as Migrants Drown. New York Times. December 26. Available online: https://www.nytimes.com/ interactive/2018/12/26/opinion/europe-migrant-crisis-mediterranean-libya.html (accessed on 9 June 2021).

Hellgren, Zenia. 2016. Immigrant Integration as a Two-Way Process: Stakeholder discourses and practices in Stockholm and Barcelona. Psychosociological Issues in Human Resource Management 4: 143-67.

Hinger, Sophie, and Reinhard Schweitzer. 2020. Politics of (Dis) Integration. Cham: Springer.

Huddleston, Thomas, Jan Niessen, and Jasper Dag Tjaden. 2013. Using EU Indicators of Immigrant Integration. Final Report for Directorate-General for Home Affairs. Available online: https:/ / ec.europa.eu/home-affairs/sites/homeaffairs/files/e-library/ documents/policies/legal-migration/general/docs/final_report_on_using_eu_indicators_of_immigrant_integration_june_20 13_en.pdf (accessed on 9 June 2021).

ISTAT. 2021. Tasso di occupazione disaggregato per sesso ed età. Available online: http:// dati.istat.it/Index.aspx?DataSetCode= DCCV_TAXOCCU1 (accessed on 9 June 2021).

Ivery, Curtis, and Joshua Bassett. 2015. Reclaiming Integration and the Language of Race in the "Post-Racial" Era. Lanham: Rowman \& Littlefield Publishers.

Kóczé, Angéla. 2021. Racialization, Racial Oppression of Roma. In The Palgrave Encyclopedia of Imperialism and Anti-Imperialism. Cham: Palgrave Macmillan.

Kundnani, Hans. 2021. What does it mean to be "pro-European" today? New Statesmen. Available online: https://www.newstatesman. $\mathrm{com} /$ world/2021/02/what-does-it-mean-be-pro-european-today (accessed on 9 June 2021).

Larsen, Christian Albrekt. 2014. Social Cohesion: Definition, Measurement and Developments. Aalborg Øst: Institut for Statskundskab, Aalborg Universitet.

Lawson, Anna, and Dagmar Schiek. 2011. European Union Non-Discrimination Law and Intersectionality: Investigating the Triangle of Racial, Gender and Disability Discrimination. New York and London: Routledge. 
Lentin, Alana. 2008. Europe and the Silence about Race. European Journal of Social Theory 11: 487-503. [CrossRef]

Magazzini, Tina. 2017. Making the most of super-diversity: Notes on the potential of a new approach. Policy E Politics 45: 527-45.

Magazzini, Tina. 2020. Integration as an Essentially Contested Concept: Questioning the Assumptions behind the National Roma Integration Strategies of Italy and Spain. In Politics of (Dis)Integration. Edited by Sophie Hinger and Reinhard Schweitzer. Cham: Springer, pp. 41-59.

McPherson, Lionel. 2015. Deflating 'Race'. Journal of the American Philosophical Association 1: 674-93. [CrossRef]

Ministero del Lavoro e delle Poliche Sociali. 2018. Eight Annual Report. For-eigners in the Italian Labour Market. Directorate General of Immigration and Integration Policies. Available online: https:/ / www.lavoro.gov.it/documenti-e-norme/studi-e-statistiche (accessed on 9 June 2021).

Montalto Monella, Lillo. 2019. Is Von der Leyen's New Commission Team Really 'as Diverse as Europe'? Euronews. September 15. Available online: https:/ / www.euronews.com/2019/09/15/is-von-der-leyen-s-new-commission-team-really-as-diverse-aseurope (accessed on 9 June 2021).

Morondo Taramundi, Dolores. 2016. Identity, Belonging and Human Rights: Cultural cues in integration processes. An introduction. The Age of Human Rights Journal 7: 1-5. [CrossRef]

Onishi, Norimitsu. 2021. Will American Ideas Tear France Apart? Some of Its Leaders Think So. The New York Times. February 9. Available online: https:/ /www.nytimes.com/2021/02/09/world/europe/france-threat-american-universities.html (accessed on 9 June 2021).

Parker, Kim, Rich Morin, and Juliana Menasche Horowitz. 2019. Pew Social Trends. Available online: https://www.pewsocialtrends. org/2019/03/21/views-of-demographic-changes-in-america/ (accessed on 9 June 2021).

Perry, Grayson. 2014. The Rise and Fall of Default Man. How Did the Straight, White, Middle-Class Default Man Take Control of Our Society-And How Can He Be Dethroned? New Statesmen. Available online: https://www.newstatesman.com/culture/2014/10/ grayson-perry-rise-and-fall-default-man (accessed on 9 June 2021).

Phillimore, Jenny, Nando Sigona, and Katherine Tonkiss. 2020. Superdiversity, Policy and Governance in Europe. Multi-Scalar Perspectives. Bristol: Policy Press, New Perspectives in Policy and Politics.

Portes, Jonathan. 2019. The Economics of Migration. Contexts 18: 12-17. [CrossRef]

Roig, Emilia. 2021. Why We Matter: Das Ende der Unterdrückung. Berlin: Aufbau Verlag.

Rosina, Alessandro. 2020. I NEET in Italia. Dati, esperienze, indicazioni per efficaci politiche di attivazione. StartNetNetwork transizione scuola-lavoro. Available online: https://www.start-net.org/sites/start-net.org/files/attachments/366/ ineetinitaliawebdef.pdf (accessed on 9 June 2021).

Roy, Olivier. 2005. La laïcité face à l'Islam. Paris: Éditions Stock Les Essais.

Schinkel, Willem. 2018. Against 'immigrant integration': For an end to neocolonial knowledge production. Comparative Migration Studies 6: 1-17. [CrossRef] [PubMed]

Sealy, Thomas, and Tariq Modood. 2021. France: From Laïcité to Laicism? In Routledge Handbook on the Governance of Religious Diversity. Edited by Anna Triandafyllidou and Tina Magazzini. London: Routledge.

Simon, Patrick. 2015. The Choice of Ignorance: The Debate on Ethnic and Racial Statistics in France. In Social Statistics and Ethnic Diversity. IMISCOE Research Series; Edited by Patrick Simon, Victor Piché and Amélie A. Gagnon. Cham: Springer, pp. 65-87.

Spencer, Sarah, and Khatarine Charsley. 2021. Reframing 'Integration': Acknowledging and addressing five core critiques. Comparative Migration Studies 9: 1-22. [CrossRef]

Triandafyllidou, Anna. 2020. Nationalism in the 21st century: Neo-tribal or plural? Nations and Nationalism 26: 792-806. [CrossRef]

Vertovec, Steven. 2007. Super-diversity and its implications. Ethnic and Racial Studies 30: 1024-54. [CrossRef]

Vidal, Frédérique. 2021. Interview de Mme Frédérique Vidal, ministre de l'enseignement supérieur, de la recherche et de l'innovation à France Culture le 4 mars 2021, sur la polémique déclenchée par le mot "islamo-gauchisme", la liberté académique et la détresse des étudiant face à la crise sanitaire. Vie Publique. Available online: https:/ / www.vie-publique.fr/discours/279113-frederiquevidal-04032021-polemique-islamo-gauchisme (accessed on 9 June 2021).

Zhou, Min. 1997. Segmented Assimilation: Issues, Controversies, and Recent Research on the New Second Generation. International Migration Review 31: 975-1008. [CrossRef] 